\title{
Injection of antibodies into the nucleus of amphibian oocytes: an experimental means of interfering with gene expression in the living cell
}

\section{ULRICH SCHEER}

Division of Membrane Biology and Biochemistry, Institute of Cell and Tumor

Biology, German Cancer Research Center, D-6900 Heidelberg, Federal Republic of Germany

\section{INTRODUCTION}

The chromatin constituents associated with transcriptionally active genes can be studied by a variety of experimental approaches. Most of the methods used involve the isolation of active chromatin fractions followed by biochemical analysis, or are based on in vitro assays with the ultimate goal of reconstituting faithful transcription by adding purified and defined components to the transcriptional machinery (for reviews see Mathis, Oudet \& Chambon, 1980; Rose, Stetler \& Jacob, 1983a; Beroldingen et al. 1984; Reeves, 1984; Dynan \& Tjian, 1985; Sentenac, 1985). Since these approaches require isolation of chromatin or of individual components therefrom, possible structural rearrangements or selective losses of certain constituents cannot a priori be excluded. Therefore it often remains questionable whether the results obtained in vitro reflect the actual situation in the living cell.

In order to examine the nature of transcriptionally active chromatin in the living cell and to decipher the in vivo function of nuclear proteins in transcriptional processes, we have microinjected antibodies to various nuclear antigens directly into the nucleus of living amphibian oocytes. The rationale behind this approach is to interfere with the function of a specific nuclear protein by loading it with an antibody. It is well established that in vitro antibodies can inactivate nuclear proteins, including certain enzymes (e.g. Ingles, 1973; Ueno, Sekimizu, Mizuno \& Natori, 1979; Sekimizu, Nakanishi, Mizuno \& Natori, 1979; Rose, Stetler \& Jacob, 1981; Stetler, Rose \& Jacob, 1981; Carroll \& Stollar, 1982; Dahmus \& Kedinger, 1983; Bréant, Huet, Sentenac \& Fromageot, 1983, Rose et al. 1983b). In addition, several studies have shown that antibodies introduced into living cells are relatively stable, preserve their antigenic specificity, bind to their respective antigens and can interfere with intracellular processes (e.g. Yamaizumi, Uchida, Mekeda \& Okada, 1979; Antman \& Livingston, 1980; Lin \& Feramisco, 1981; Bennett, Busch, Lischwe \& Yeoman, 1983; McGarry, Hough, Rogers \&

Key words: nucleus, amphibian oocyte, microinjection, antibodies, lampbrush chromosomes, transcription, RNA polymerases, chromatin, actin. 
Rechsteiner, 1983; Stacey \& Allfrey, 1984; Mercer, Avignolo \& Baserga, 1984a; Burke \& Warren, 1984; Blose, Meltzer \& Feramisco, 1984; Schlegel, Miller \& Rose, 1985).

Amphibian oocytes represent the material of choice for studying the effects of microinjected antibodies. The lampbrush chromosomes and the amplified nucleoli serve as convenient indicators to monitor the specific transcriptional activity of an individual cell (see below). Furthermore, biochemical analyses such as determination of the rate of rRNA synthesis by gel electrophoresis or of the transcription of a specific gene and processing of the pre-mRNA by Northern analysis require only a few oocytes (see below).

Although amphibian oocytes are highly specialized cells, the results obtained with this experimental system appear to be of general significance. As will be discussed below, essentially identical results have been obtained with cultured mammalian cells after introduction of the comparable antibodies.

\section{LAMPBRUSH CHROMOSOMES AS INDICATORS OF TRANSCRIPTIONAL ACTIVITY}

Lampbrush chromosomes are isolated from amphibian oocytes and prepared for light microscopical examination in a buffer of physiological ionic strength as outlined in detail by Callan \& Lloyd (1960) and Gall (1966). A chromosome bivalent with two paired homologous chromosomes is shown in Fig. 1A. It is advisable to use lampbrush chromosomes from urodelan (newts and salamanders) oocytes because their chromosomes are much larger compared with anuran (e.g. Xenopus) oocytes. Interestingly, the sizes of the lampbrush chromosomes including the lateral loops appear to be correlated to the chromosomal DNA content of the specific species (Scheer \& Sommerville, 1982). Each chromosome consists of a dense central axis (which appears as a linear array of dense nodular structures, the 'chromomeres') and numerous lateral loops with contour lengths usually ranging from 20 to $50 \mu \mathrm{m}$; occasionally 'giant' loops with axial lengths of $100 \mu \mathrm{m}$ or more are also found. Especially the larger loops reveal the presence of an asymmetrically distributed matrix coat so that a thin and a thick end of a loop can be distinguished (Fig. 1B, inset; see also Scheer, Spring \& Trendelenburg, $1979 b)$.

When lampbrush chromosomes are isolated under almost native conditions as described above, followed by fixation and embedding for electron microscopy ('end-embedding technique'; Mott \& Callan, 1975; Spring \& Franke, 1981), ultrathin sections reveal the high density of nascent RNP transcripts which in their entirety constitute the finely fibrillar matrix coat as seen in phase contrast microscopy (Fig. 1B). Each transcript fibril consists of a linear array of $25-40 \mathrm{~nm}$ thick RNP particles. Due to the high number and packing density of the RNP transcripts the underlying chromatin axis is hardly visible.

The ultrastructural organization of the transcription units of the lateral loops of the lampbrush chromosomes is best visualized in electron microscopic preparations using the chromatin spreading technique of Miller and colleagues 

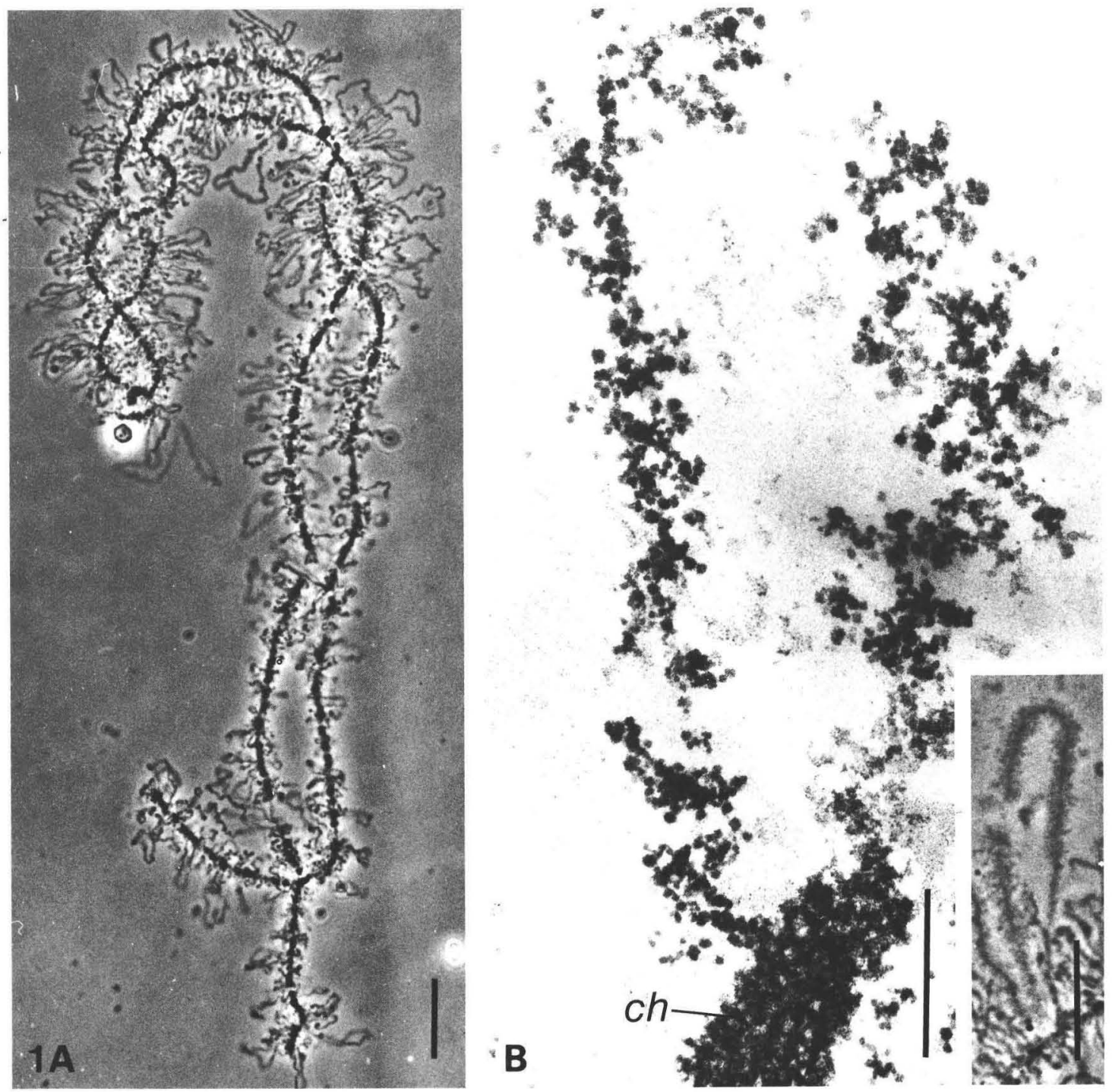

Fig. 1. Light microscopic ( $A$ and inset of $B$; phase contrast) and electron microscopic (B; ultrathin section) appearance of lampbrush chromosomes from newt oocytes (A, from Pleurodeles waltlii: B, from Triturus cristatus). The survey electron micrograph of B shows a single lateral loop of a flat-embedded chromosome extending from a dense chromomere (ch). The chromatin axis is hardly visible due to the presence of numerous RNP transcripts with a globular subunit structure. For comparison, a loop with asymmetrically distributed RNP matrix coat as seen in the light microscope is shown in the inset of B. Bars, $20 \mu \mathrm{m}$ (A and inset in B) and $0.5 \mu \mathrm{m}(\mathrm{B})$.

(Fig. 2A,B; for reviews see Scheer, Spring \& Trendelenburg, 1979b; Miller, 1981). The RNA polymerases are extremely densely spaced and often form an almost continuous thickening of the chromatin axis (Fig. 2A,B). Since the chromosomes have been exposed during the spreading to very low ionic strengths, the higher 
order compaction of the transcripts is lost and they appear as thin RNP fibrils. In the proximal regions of a transcription unit, the transcripts are arranged in a length gradient that reflects the progressive growth of the RNA chains contained
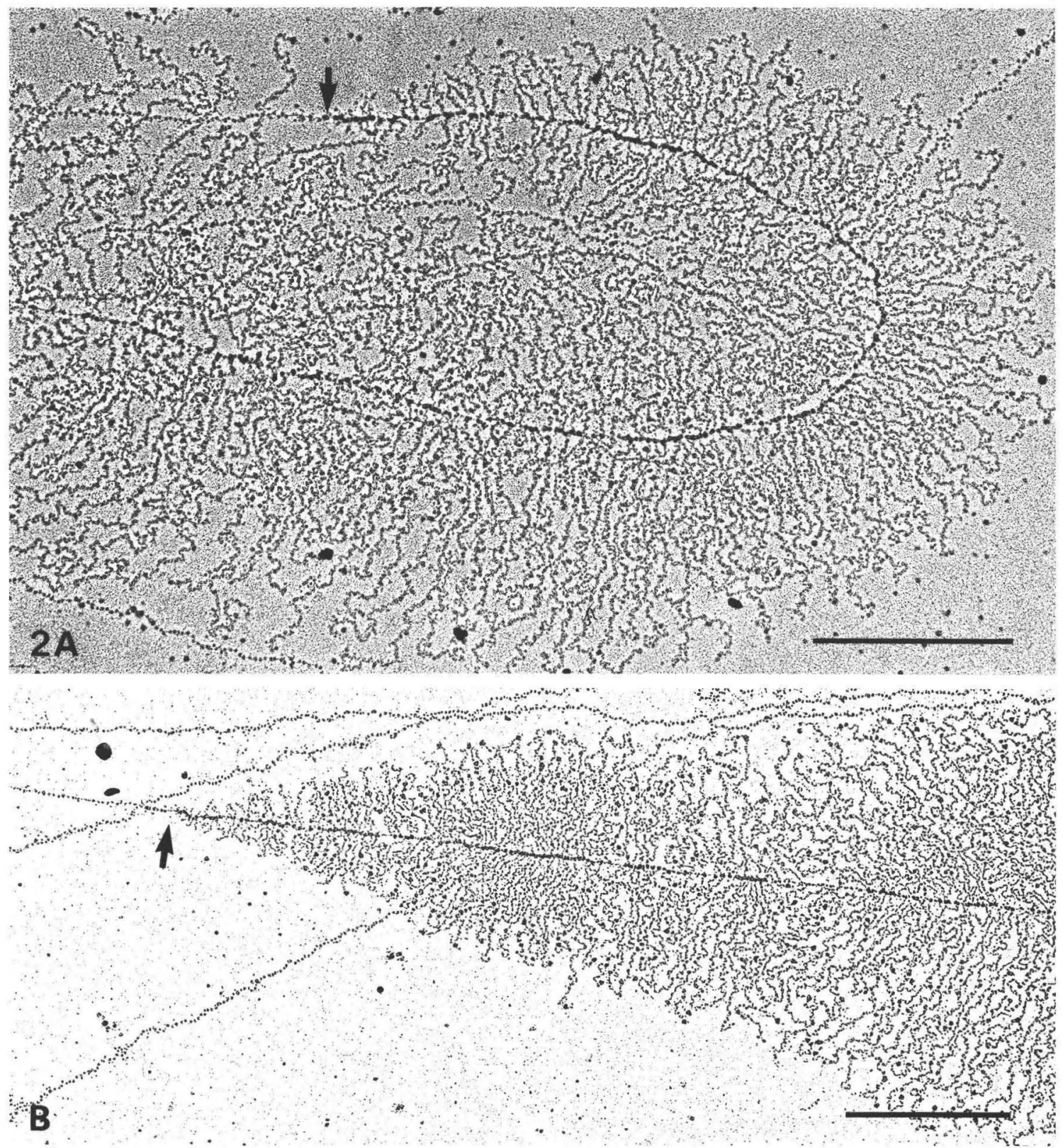

Fig. 2. Electron microscopic spread preparations of lampbrush chromosomes from Pleurodeles waltlii. Note the extremely high packing density of nascent transcripts. Chromatin regions upstream of the transcription initiation sites (indicated by arrows) reveal a beaded, nucleosomal arrangement. Bars, $1 \mu \mathrm{m}$. 
(Fig. 2A,B). Thus, the 'thin' end of a lateral loop as seen in light microscopy corresponds to the start region of a transcription unit and the 'thick' end to its terminal region.

Inhibition of transcription by drugs such as actinomycin D (AMD), $\alpha$-amanitin or 5,6-dichloro-1- $\beta$-D-ribofuranosylbenzimidazole (DRB) is accompanied by dramatic changes in the morphology of the chromosomes. The lateral loops retract with time and at about $4 \mathrm{~h}$ after application of the drugs loops are no longer detectable in light microscopic preparations (Fig. 3C,D) As seen in spread preparations the retraction of the lateral loops is accompanied by a premature release of the transcripts from the chromatin axis (Fig. 3E,F). Since this effect is generally observed after transcriptional inactivation independent of the specific kind of inhibitor or its mode of action, the loop retraction process can be taken as a sensitive and reliable indicator of inhibition of RNA polymerase II-dependent transcription.

Loop retraction involves a higher order compaction of the chromatin axis immediately following the release of transcripts. When the transcripts are more distantly spaced the chromatin axis first folds up into nucleosomes (Fig. 3F) and then, provided that the transcripts are sufficiently apart, into a higher order $30 \mathrm{~nm}$ thick fibril (Fig. 3H).

MORPHOLOGY OF TRNA GENES AS A FUNCTION OF TRANSCRIPTIONAL ACTIVITY

In electron microscopic spread preparations intensely transcribed rRNA genes reveal the characteristic 'Christmas tree'-like appearance with a maximal packing density of the transcript fibrils (Fig. 4A; for details see Miller, 1981; Scheer \& Zentgraf, 1982). In states of reduced transcriptional activity the coverage density with RNA polymerases is reduced (Scheer, Trendelenburg \& Franke, 1976). Inhibition of transcription by AMD or other DNA intercalating drugs leads to a rapid premature transcript release from the nucleolar chromatin (Fig. 4B; Scheer, Trendelenburg \& Franke, 1975). Consequently, the maintained appearance of rRNA genes fully loaded with RNA polymerases after introduction of antibodies into the cell nucleus shows that polymerase I-dependent transcription is not perturbed.

SELECTIVITY OF ANTIBODY ACTION AND ACCESSIBILITY OF THE

TRANSCRIPTIONAL APPARATUS TO IMMUNOGLOBULINS

(A) Injection of antibodies to RNA polymerase II

Injection of purified rabbit IgG against RNA polymerase II into nuclei of Pleurodeles oocytes induces an immediate retraction of all lateral loops (Fig. 5A; the chromosomes were isolated 5 min after injection; for details see Bona, Scheer \& Bautz, 1981). After introduction of reduced amounts of antibodies the loop retraction process is somewhat delayed and intermediate stages can be analysed. The electron microscopic spread preparation of Fig. 5B shows that loop retraction 

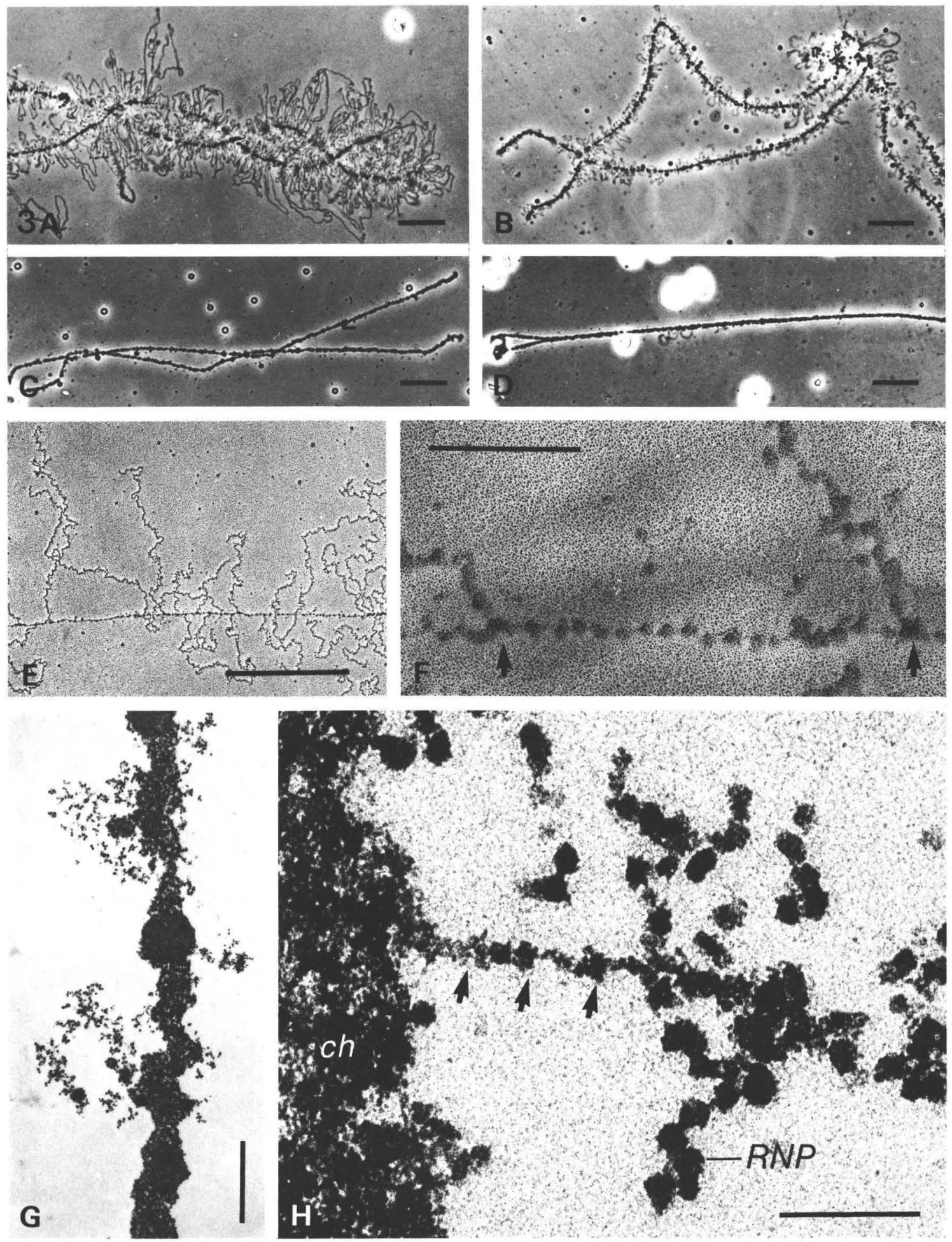
is accompanied by a dramatic loss of transcripts from the chromatin axis. Moreover, free, apparently prematurely released transcripts are abundantly present in such preparations (Fig. 5C). That transcription of rRNA genes is not affected can be demonstrated by two different approaches. First, electron microscopic spread preparations show that rRNA genes retain their high packing density of transcripts (Fig. 5B). Second, the amount of newly synthesized rRNA is not reduced by antibody injection as shown by gel electrophoresis of total oocyte RNA radioactively labelled by intracellular injection of $\left[{ }^{32} \mathrm{P}\right]$ ribonucleotides (Fig. 5D). Furthermore, polymerase III-dependent transcription is also not affected, as cloned tRNA genes coinjected along with antibodies synthesize tRNA in similar amounts to controls lacking the antibody (Fig. 5E).

The very rapid premature release of the nascent transcripts from the chromatin fibres suggests that the antibodies act directly on the template-engaged RNA polymerases. Binding of the antibodies to the polymerases seems to interfere with the association of the enzyme complex with the chromatin template. In contrast, certain monoclonal antibodies directed against the large subunit of RNA polymerase II appear to inhibit the initiation but not the elongation reaction, since after microinjection they cause a relatively slow retraction of the loops (Bona et al. 1981). It has also been reported that certain monoclonal antibodies to RNA polymerase II prevent the formation of enzyme-DNA complexes in vitro (Carroll \& Stollar, 1982).

\section{(B) Injection of antibodies to RNA polymerase I}

Patients suffering from the systemic autoimmune disease scleroderma often develop autoantibodies to RNA polymerase I which react with the nucleolar enzyme of a wide variety of species, including Amphibia (Reimer, Rose, Scheer \& Tan, 1986). After microinjection of the purified IgGs into nuclei of Xenopus oocytes, followed by injection of $\left[{ }^{32} \mathrm{P}\right] \mathrm{GTP}$, autoradiography of the electrophoretically separated RNA demonstrates a drastic reduction in rRNA synthesis as compared to controls (Fig. 6A). When the same antibodies are injected into the cytoplasm, transcription of the rRNA genes is not affected at all (Fig. 6A),

Fig. 3. Loop retraction as seen in light microscopic preparations of lampbrush chromosomes after exposure of Triturus oocytes to a medium containing $50 \mu \mathrm{g} \mathrm{ml}^{-1}$ actinomycin D (A, control; B, $2 \mathrm{~h} ; \mathrm{C}, 5 \mathrm{~h})$ and after microinjection of $\alpha$-amanitin into Pleurodeles oocytes (D, $1 \mathrm{~h}$ after injection). Electron microscopic spread preparations of retracting loops illustrate the reduced packing density of nascent transcripts (E,F; attachment sites of two distantly spaced transcripts are indicated by arrows in F). The intragenic chromatin regions free of transcripts have a beaded, nucleosomal structure (F). Lampbrush chromosomes in stages of very low transcription (4h AMD) are shown, after isolation under almost native conditions followed by fixation and flatembedding for electron microscopy, in ultrathin sections $(\mathrm{G}, \mathrm{H})$. Small loops with attached RNP transcripts are detectable along the prominent central chromosome axis (G). Loop chromatin is condensed into about $30 \mathrm{~nm}$ thick fibres (arrows in $\mathrm{H}$ ) to which RNP transcripts are still attached. $c h$, chromomere. Bars, $20 \mu \mathrm{m}(\mathrm{A}-\mathrm{D}) ; 1 \mu \mathrm{m}(\mathrm{E}, \mathrm{G})$; $0 \cdot 2 \mu \mathrm{m}(\mathrm{F}, \mathrm{H})$. 
indicating that $\mathrm{IgG}$ molecules do not readily cross the nuclear envelope (see also McGarry, Hough, Rogers \& Rechsteiner, 1983; Einck \& Bustin, 1984; Stacey \& Allfrey, 1984; Sugawa, Inamoto, Wataya-Kaneda \& Uchida, 1985).

In somatic cells, nucleolar RNA synthesis is also considerably reduced when antibodies to RNA polymerase I are either microinjected directly into the nucleus or introduced into mitotic cells via erythrocyte-mediated transfer (Mercer et al. 1984; Schlegel et al. 1985). The inhibitory action of polymerase I-antibodies clearly

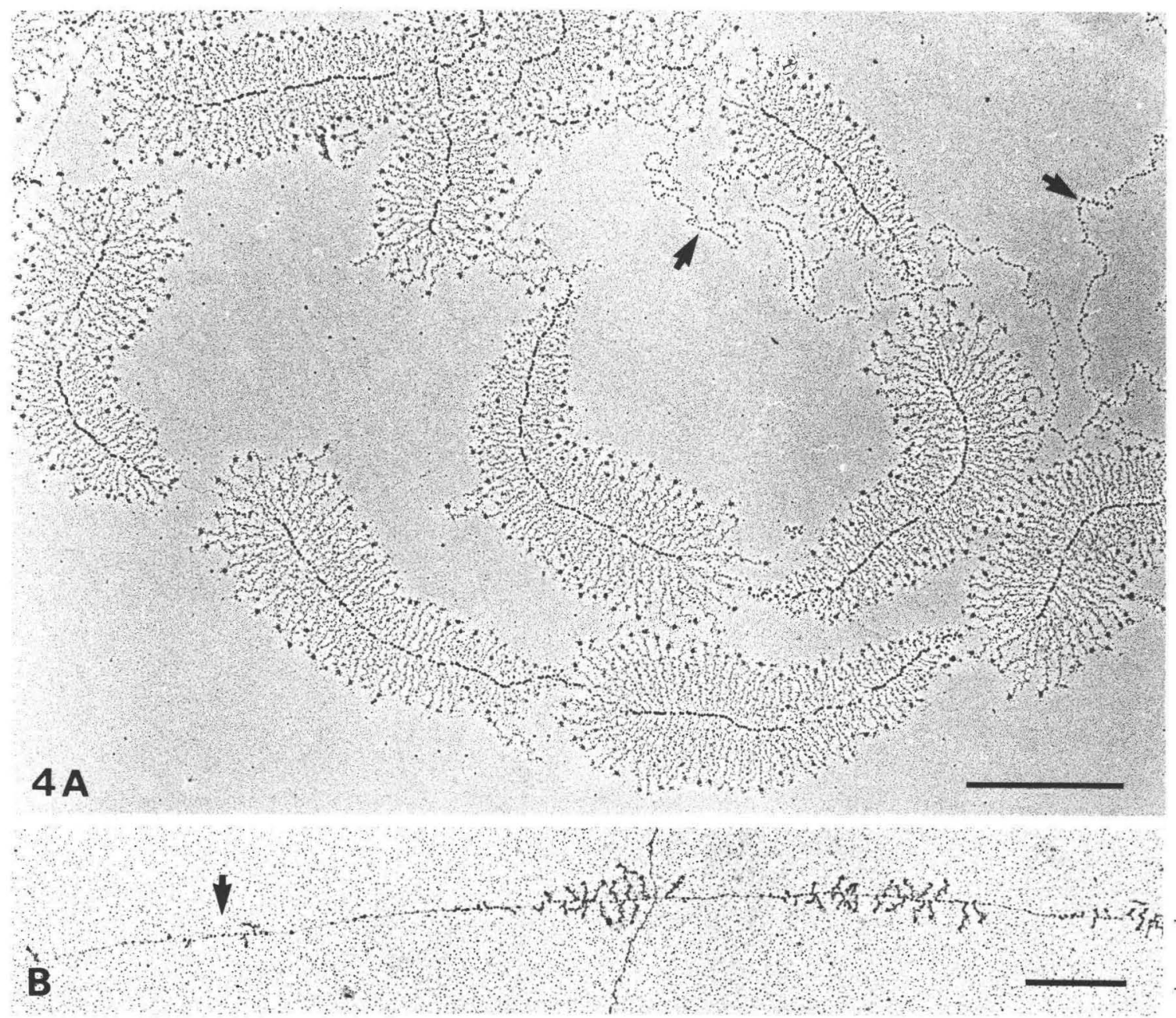

Fig. 4. Electron microscopic appearance of spread rRNA genes from a growing Pleurodeles oocyte (A). All genes appear to be fully active as indicated by the high packing density of transcripts. The nontranscribed spacers separating adjacent genes are relatively short in this species. Note the beaded character of a transcriptionally inactive chromatin strand (arrows). (B) After incubation of Pleurodeles oocytes with the DNA-intercalating drug Rudolphomycin $\left(10 \mu \mathrm{g} \mathrm{ml}^{-1}, 1 \mathrm{~h}\right)$, the number of transcripts per rRNA gene is considerably reduced. The arrow in B denotes an almost inactive rRNA gene. Bars, $1 \mu \mathrm{m}$. 
shows that $\operatorname{IgG}$ molecules can penetrate the compact nucleolar structure in the living cell and have access to the active rRNA genes inside the nucleolus.

\section{(C) Injection of antibodies to DNA}

A monoclonal antibody (IgM) directed against both double- and single-stranded DNA binds to nuclear chromatin in the living cell (Fig. 6B; for a detailed characterization of the antibody see K. Messner, Diploma thesis, University of Heidelberg, 1985). Following injection into the cytoplasm of mitotic PtK2-cell, the newly formed daughter nuclei show intense staining when examined by immunofluorescence microscopy whereas adjacent cells are totally negative (Fig. 6B). When the same antibodies are injected into the nucleus of a Pleurodeles oocyte, the lampbrush chromosome loops retract within a time span of about $3 \mathrm{~h}$. In this case transcription is inhibited by binding of the antibodies to the loop DNA, thereby blocking the progression of the RNA polymerases along the chromatin axis. Interestingly, microinjected DNA-antibodies do not inhibit rDNA transcription (Fig. 6A) which possibly reflects the inaccessibility of the nucleolar chromatin to the large IgM molecules.

COMPOSITION OF TRANSCRIPTIONALLY ACTIVE CHROMATIN

\section{(A) Histones}

Morphological evidence presented above provides clear evidence that histones are present on loop chromatin of lampbrush chromosomes in states of reduced transcriptional activity (Fig. 3 F,H). In order to allow for transcription, a nucleosome has to unfold. This unfolding process might involve a mere structural rearrangement of the nucleosome or a transient dissociation of histones from the DNA (for recent discussions on the association of histones with active chromatin cf. Baer \& Rhodes, 1983; Karpov, Preobrazhenskaya \& Mirzabekov, 1984; Sargan $\&$ Butterworth, 1985). If histones are actually displaced from the DNA during the transcriptional process, then a rapid succession of transcriptional events such as in the highly active lampbrush chromosome loops should manifest itself in an apparent absence of histones.

Injection of purified immunoglobulins to histone $\mathrm{H} 2 \mathrm{~B}$ causes a time-dependent progressive foreshortening of the lateral loops (Scheer et al. 1979). Within 3-4h after injection, the loops are completely retracted into the chromosome axes. This result indicates that histone $\mathrm{H} 2 \mathrm{~B}$ and possibly also the other core histones remain associated with heavily transcribed chromatin regions and that binding of antibodies to $\mathrm{H} 2 \mathrm{~B}$ prevents the passage of the RNA polymerases along the chromatin axis. In fact, the presence of histone H2B can also be directly demonstrated on transcribed chromatin of lampbrush loops by immunogold-electron microscopy (data not shown).

The general conclusion that histones remain in close association with RNA polymerase II transcription complexes is also supported by microinjection of antibodies to histones $\mathrm{H} 3, \mathrm{H} 2 \mathrm{~A}$ and $\mathrm{H} 2 \mathrm{~B}$ into nuclei of human fibroblasts. These 

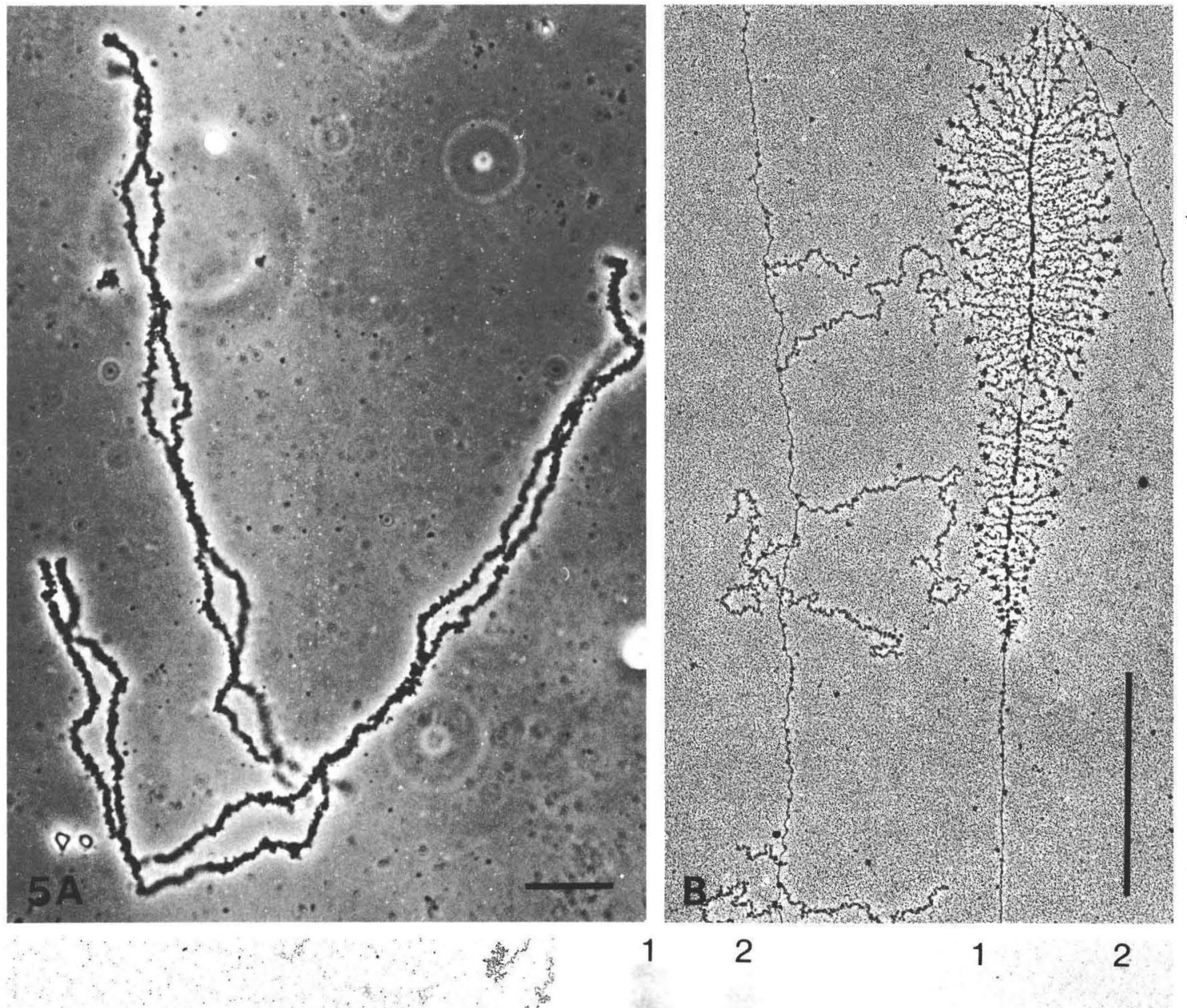

12

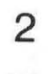

1

2

(4) 3

bonto $\frac{}{4}+4$

है का

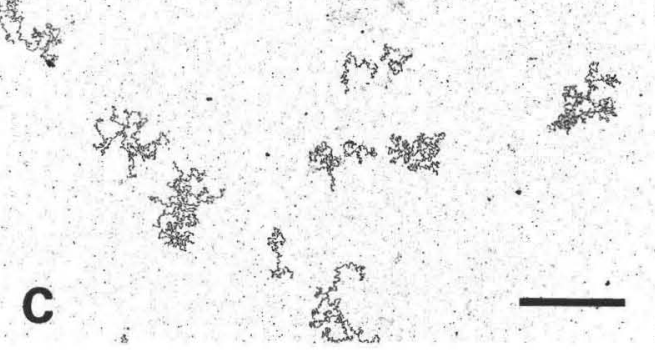

$-40 S$

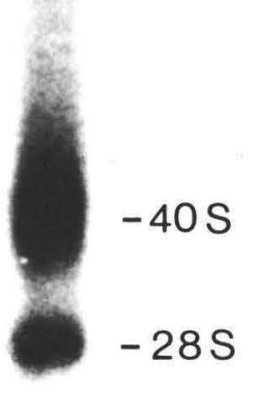

stivf $-18 \mathrm{~S}$

D

E 
antibodies efficiently reduce transcription as visualized by $\left[{ }^{3} \mathrm{H}\right]$ uridine incorporation and autoradiography (Einck \& Bustin, 1983).

It is interesting to note that the injected antibodies to $\mathrm{H} 2 \mathrm{~B}$ do not interfere with transcription of the rRNA genes (Scheer et al. 1979). In view of the finding that the amplified nucleoli are accessible to IgGs (see above), the negative outcome of this injection experiment might indicate the absence of histone $\mathrm{H} 2 \mathrm{~B}$ and possibly also the other core histones from transcriptionally active nucleolar chromatin which is characterized by an extended, non-nucleosomal configuration (reviewed by Scheer \& Zentgraf, 1982). However, other explanations such as masking or changes of histone epitopes could also explain such a selective, negative result.

\section{(B) High mobility group $(H M G)$ proteins}

The HMG-proteins represent a well-characterized family of nonhistone chromosomal proteins of relatively low molecular masses $\left(M_{\mathrm{r}} 7000-28000\right.$; for a review see Johns, 1982). Several studies have indicated a role for HMG-proteins 14 and 17 in maintaining an altered, DNAse I-sensitive conformation of active chromatin (Weisbrod, 1982). The function of HMG-1 and -2, which are also integral constituents of chromatin, is less clear. Some authors have found a specific association with active chromatin fractions whereas others could not confirm these observations (for references see Kleinschmidt et al. 1983). Besides being bound to DNA, HMG-1-1ike proteins occur also as nonchromatin-bound, soluble molecules both in the nucleus and the cytoplasm of amphibian oocytes (Kleinschmidt et al. 1983).

Upon injection of purified rabbit antibodies (IgG) to the HMG-14/17 and HMG-1/2 subclass into Pleurodeles oocyte nuclei, a progressive retraction of the chromosomal loops is seen (Fig. 7). Within about $3 \mathrm{~h}$ all lateral loops are collapsed and integrated into the chromosome axes (Fig. 7E). Antibodies to HMG-1 do not interfere with transcription of the rRNA genes as the close packing density of their transcripts is retained. In somatic cells, transcription is also inhibited by injection of antibodies to HMG-17, but not by antibodies to HMG-1 (Einck \& Bustin, 1983).

Fig. 5. Injection of antibodies to RNA polymerase II causes immediate loop retraction (A; lampbrush chromosomes isolated 5 min after injection into nuclei of Pleurodeles oocytes; phase contrast). Intermediate stages of loop retraction after injection of reduced amounts of antibodies are characterized by a progressive release of transcript fibrils from the chromatin template (B; electron microscopic spread preparation). The rRNA genes are apparently not affected by the antibodies. (C) Numerous prematurely released RNP transcripts in a spread preparation. (D,E) Gel electrophoresis of RNA from Xenopus oocytes as seen by autoradiography. (D) Injection of $\left[{ }^{32} \mathrm{P}\right] \mathrm{CTP}$ into the nuclei of Xenopus oocytes without (lane 1) and together with $24 \mathrm{ng}$ anti-RNA polymerase II-IgG per nucleus (lane 2 ). RNA was extracted $3 \mathrm{~h}$ later and analysed on a $1.2 \%$ agarose gel. (E) Synthesis of tRNA after injection of cloned tRNA genes along with $\left[{ }^{3} \mathrm{H}\right] \mathrm{UTP}$ in the absence (lane 1 ) and presence of $60 \mathrm{ng}$ IgG per nucleus (lane 2). RNA was extracted $6 \mathrm{~h}$ later and analysed on a $10 \%$ polyacrylamide/urea gel. Bars, $20 \mu \mathrm{m}$ (A); $1 \mu \mathrm{m}$ (B); $2 \mu \mathrm{m}$ (C). 


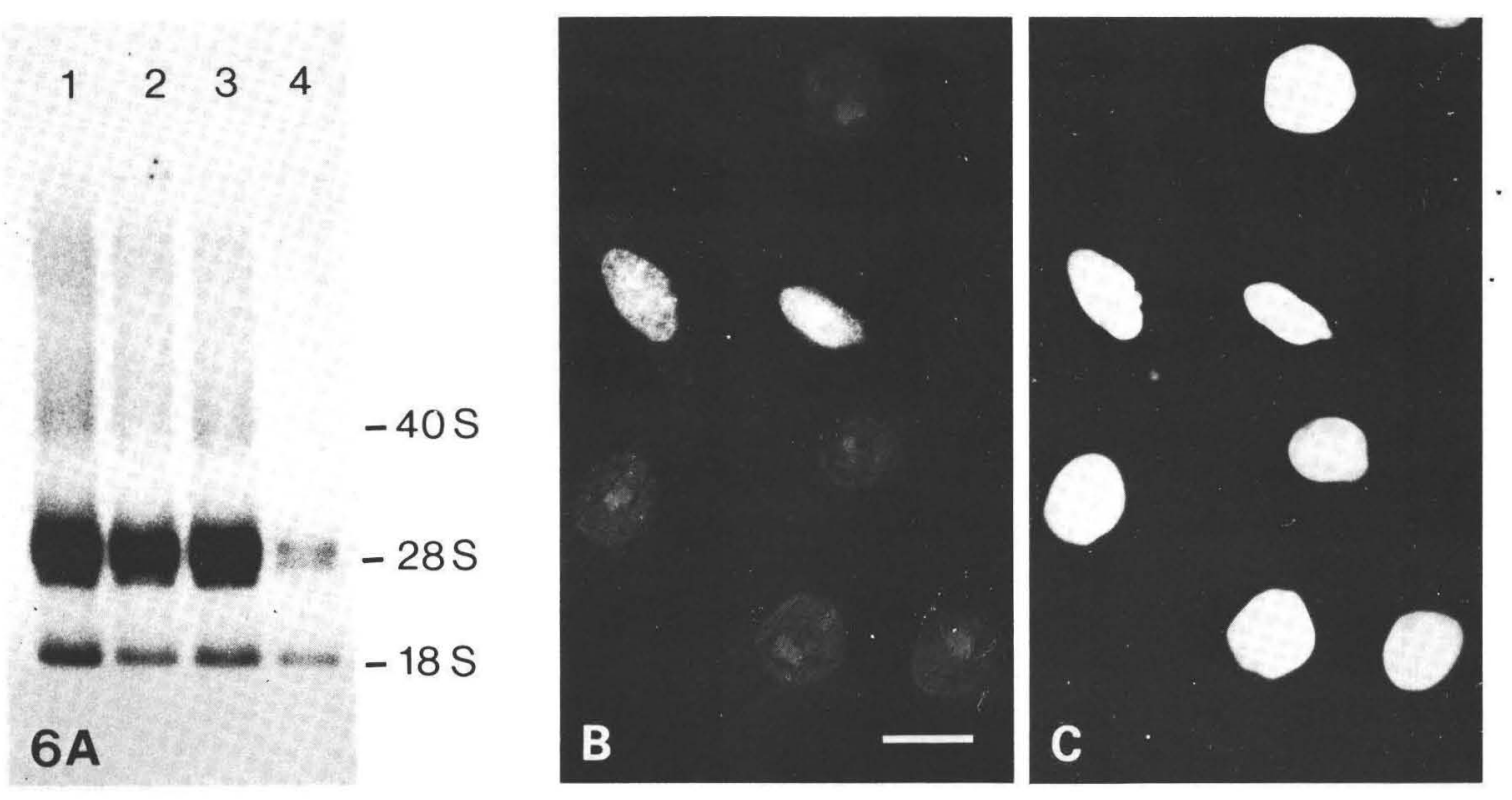

Fig. 6. (A) Analysis of total oocyte RNA of Xenopus laevis by gel electrophoresis (1.5\% agarose gel) and autoradiography after microinjection of antibodies. Lane 1, control (intranuclear injection of buffer alone); lane 2, intranuclear injection of monoclonal anti-DNA IgM $\left(1.1 \mathrm{mg} \mathrm{ml}^{-1}\right)$; lanes 3 and 4 , injection of purified Igfraction $\left(1.8 \mathrm{mg} \mathrm{ml}^{-1}\right)$ of serum obtained from a scleroderma patient with antipolymerase I specificity into the cytoplasm (lane 3 ) and nucleus (lane 4 ). $2 \mathrm{~h}$ following the injections the oocytes received another injection of equal amounts of $\left[{ }^{32} \mathrm{P}\right] \mathrm{GTP}$ into the cytoplasm. $6 \mathrm{~h}$ later RNA was extracted. RNA corresponding to two oocytes each was applied to each gel lane.

(B,C) Immunofluorescence microscopy of cultured rat kangaroo (PTK2) cells. DNA antibodies were microinjected into a mitotic PTK2-cell grown on a coverslip. $2 \mathrm{~h}$ later the specimen was fixed in methanol at $-20^{\circ} \mathrm{C}$ for $10 \mathrm{~min}$, then in acetone at $-20^{\circ} \mathrm{C}$ for $1 \mathrm{~min}$, air dried and incubated with FITC-labelled goat anti-mouse IgM antibodies for $20 \mathrm{~min}$. Nuclei of the two daughter cells are fluorescing in contrast to adjacent cells which did not receive the antibody (B). Same preparation after addition of the fluorescing DNA-specific dye DAPI in order to visualize all cell nuclei (C). Bar, $20 \mu \mathrm{m}$.

Taken together, these results suggest that HMG-proteins are present on transcriptionally active chromatin regions in very close proximity to the transcriptional complexes. Whether HMG-1 is specifically involved in lampbrush loop transcription in contrast to somatic cells remains to be established.

\section{(C) DNA topoisomerase I}

DNA topoisomerase I (topo I) is an enzyme $\left(M_{\mathrm{r}}\right.$ about 100000) that alters the topological state of DNA (for a review see Wang, 1985). Recent studies based on immunofluorescence microscopy have shown that topo I localizes to transcriptionally active chromatin regions and is especially enriched in the nucleolus (Fleischmann et al. 1984; Muller, Pfund, Mehta \& Trask, 1985). The striking 
colocalization between active chromatin and topo I suggests a functional role for the enzyme in transcriptional processes in general (see Wang, 1985).

Antibodies raised in rabbits against purified calf thymus topo I react with the corresponding enzyme of a variety of species including Amphibia (A. Richter, R. Knippers \& U. Scheer, unpublished data). Since the antibodies inhibit the
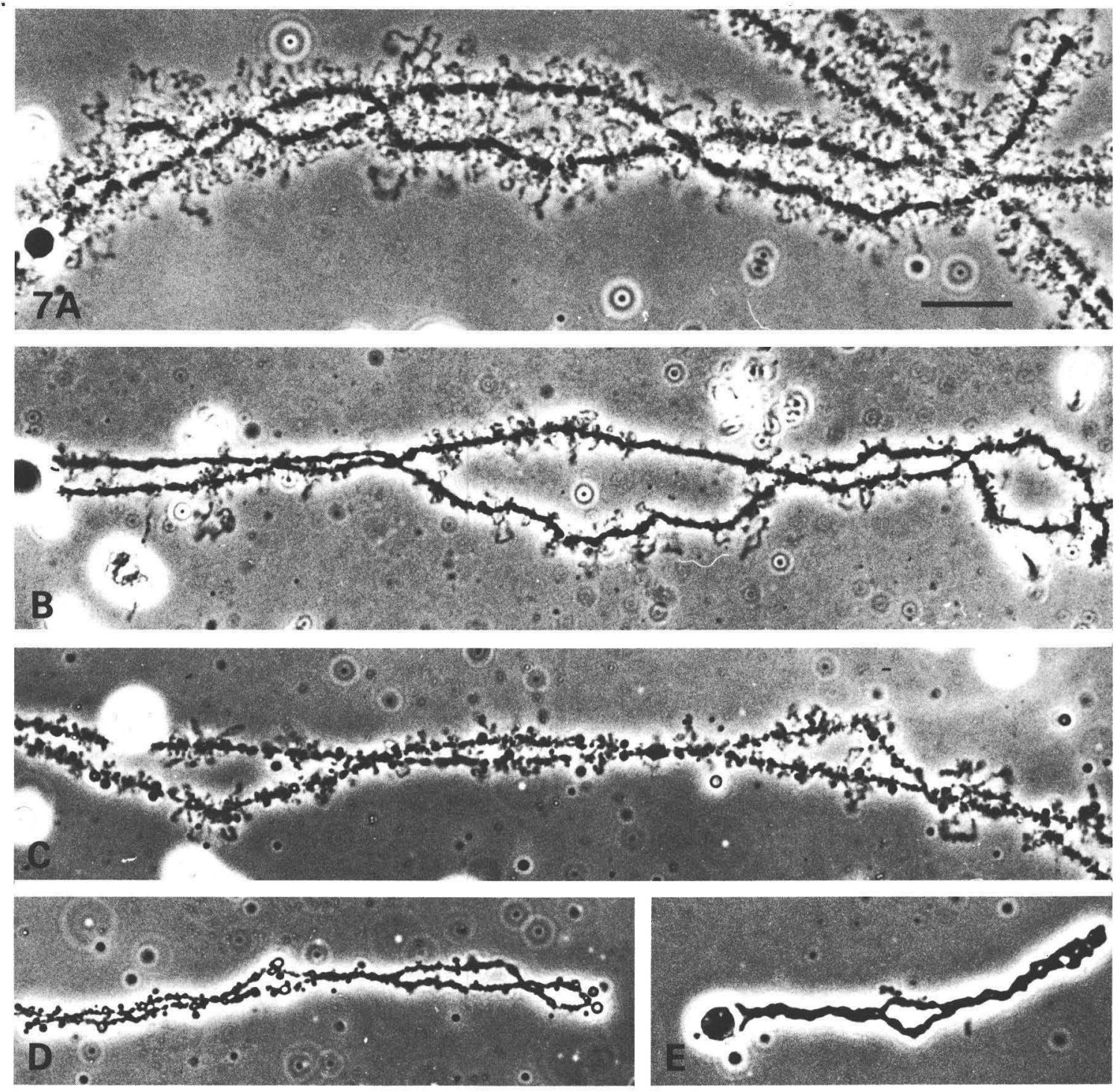

Fig. 7. Time-dependent progressive retraction of the lateral loops of Pleurodeles lampbrush chromosomes after intranuclear injection of antibodies to HMG-1 as seen by phase contrast microscopy. (A) Control after injection of nonimmune rabbit $\mathrm{IgG}$ $\left(2 \mathrm{mg} \mathrm{ml}^{-1}\right)$; (B) $30 \mathrm{~min}$; (C) $40 \mathrm{~min}$; (D) $60 \mathrm{~min}$; (E) $3 \mathrm{~h}$ after injection of purified antiHMG-1 IgG $\left(1.8 \mathrm{mg} \mathrm{ml}^{-1}\right)$. All photographs are magnified to the same scale. Bar, $20 \mu \mathrm{m}$. 
ability of topo I to relax supercoiled DNA in vitro (A. Richter, unpublished data) we hope that microinjection of these antibodies into amphibian oocyte nuclei will allow us in the near future to clarify whether topo I is functionally involved in transcriptional processes in vivo.

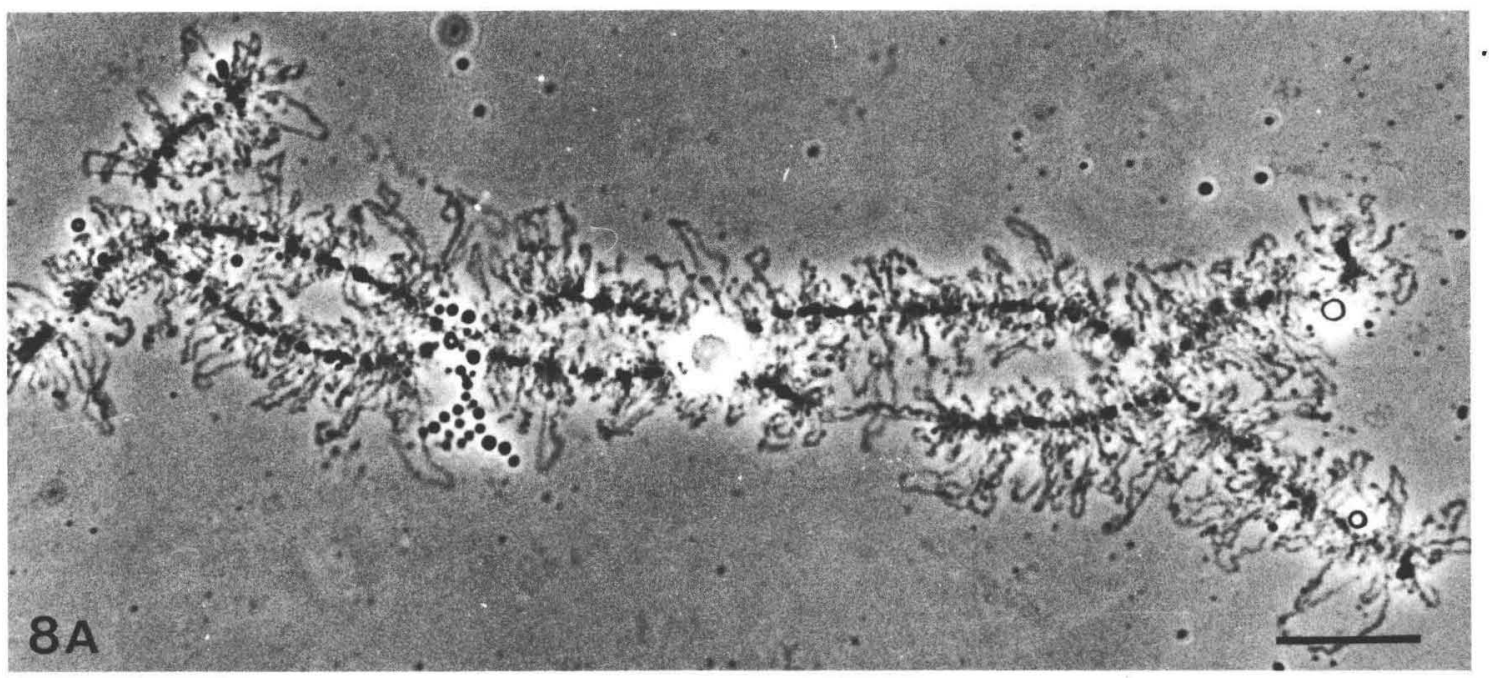

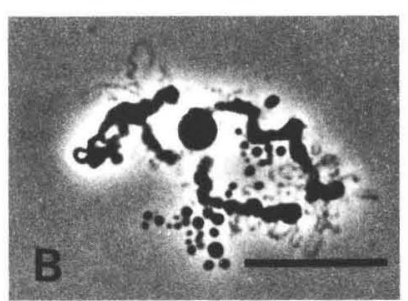

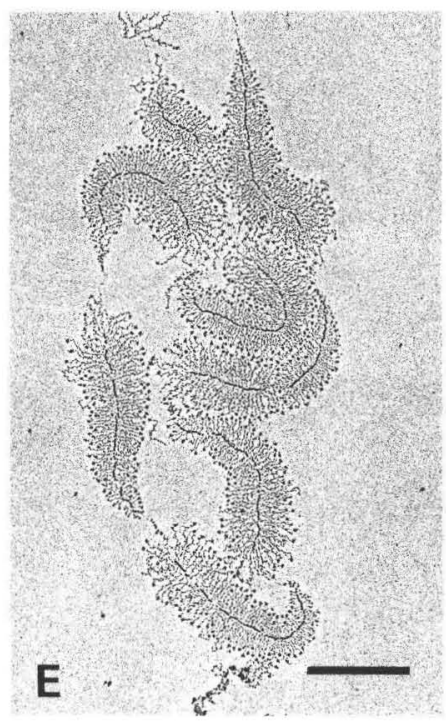

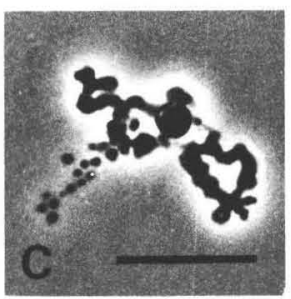
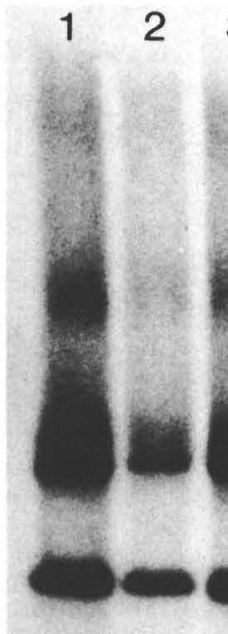

F
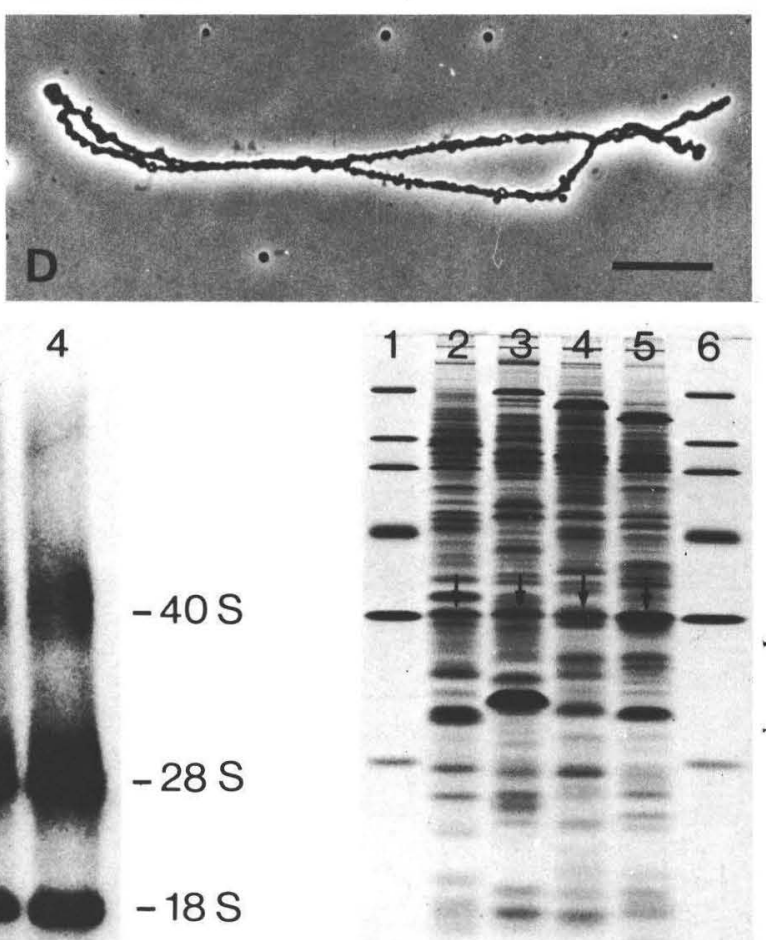

G 
INVOLVEMENT OF NUCLEAR ACTIN IN TRANSCRIPTION

Actin is a major protein of cell nuclei and is particularly enriched in the nucleoplam of amphibian oocytes (Fig. 8G; for references see Scheer, Hinssen, Franke \& Jockusch, 1984). Most of the nuclear actin, which is $\beta$ - and $\gamma$-nonmuscle actin, occurs in a nonfilamentous, soluble form. So far the functional significance of nuclear actin is not clear. However, microinjection of actin-binding proteins and antibodies to actin into amphibian oocyte nuclei has indicated that this protein, besides other possible functions, plays an unexpected role in transcriptional processes mediated by RNA polymerase II (Scheer et al. 1984).

Injection of actin-binding protein fragmin results, within $2-3 \mathrm{~h}$, in the progressive retraction of most lateral loops (Fig. 8B,C). The same effect is observed upon injection of affinity-purified rabbit antibodies to $\beta$ - and $\gamma$-actin (Fig. 8D). The inhibition of transcription is specific for polymerase II-dependent genes, since rRNA genes are not affected as shown by electron microscopic spread preparations (Fig. 8E) or gel electrophoresis of newly synthesized RNA (Fig. 8F).

How is nuclear actin involved in transcriptional events of protein-coding genes? At least two mechanisms might be envisaged. (i) The soluble monomeric or oligomeric nuclear actin interacts directly with the transcriptional machinery similar to a transcription factor. This possibility is supported by the finding that a protein factor necessary for correct initiation in vitro of polymerase II-dependent transcription contains actin (Egly, Miyamoto, Moncollin \& Chambon, 1984). (ii) Although the majority of nuclear actin occurs in a soluble form, a few existing actin microfilaments might be critically involved in release of transcripts from the template and/or in subsequent intranuclear and nucleocytoplasmic translocation of RNP products (see also Nakayasu \& Ueda, 1985).

\section{DOES Z-DNA EXIST IN TRANSCRIBED LAMPBRUSH CHROMOSOME LOOPS?}

Since the discovery that the occurrence of left-handed Z-DNA conformations in polytene chromosomes of Drosophila seemed to correlate with transcriptional activity (Nordheim et al. 1981; for possible artifacts caused by the acid fixation of

Fig. 8. Retraction of lateral loops of lampbrush chromosomes as seen by phase contrast microscopy after intranuclear injection of the actin-binding protein fragmin $(\mathrm{B}, \mathrm{C})$ and actin-antibodies (D; affinity-purified IgGs, $0.2 \mathrm{mg} \mathrm{ml}^{-1}$ ). A, control; B, $2 \mathrm{~h} ; \mathrm{C}, 4 \mathrm{~h}$ after fragmin injection; $\mathrm{D}, 4.5 \mathrm{~h}$ after anti-actin injection. The transcription of the rRNA genes is not affected as seen in electron microscopic spread preparations (E). (F) Analysis of Pleurodeles RNA by $1.5 \%$ agarose gel electrophoresis and autoradiography. Lane 1, injection of anti-actin; lane 2, injection of fragmin; lane 3, injection of another actin-modulating protein (see Scheer et al. 1984); lane 4, injection of buffer alone. $3 \mathrm{~h}$ later each oocyte received an equal amount of $\left[{ }^{32} \mathrm{P}\right] \mathrm{GTP}$ by injection into the cytoplasm. RNA was extracted $5 \mathrm{~h}$ later. RNA corresponding to three oocytes each was applied to each lane. (G) Analysis of nuclear proteins from amphibian oocytes by SDS-polyacrylamide gel electrophoresis and Coomassie-blue staining. Nuclear proteins from oocytes of Xenopus laevis (lane 2), Pleurodeles waltlii (lane 3), Rana temporaria (lane 4) and Rana esculenta (lane 5). Arrows denote actin. Reference proteins are (from top to bottom in lanes 1 and 6) myosin heavy chain, $\beta$-galactosidase, phosphorylase a, bovine serum albumin, actin, and chymotrypsinogen. 
chromosomes see Lancillotti, Lopez, Alonso \& Stollar, 1985), the possible role of Z-DNA formation in gene regulation has received much attention. Since microinjected monoclonal antibodies to the B-form DNA efficiently inhibit transcription of the lampbrush loops (see above), this experimental approach has been used to examine the possible existence of Z-DNA in the transcribed loops in vivo. Various monoclonal antibodies specific to Z-DNA (provided by Dr R. Thomae, Progen Biotechnic, Heidelberg; see also Pohl, Thomae \& DiCapua, 1982; Thomae, Beck \& Pohl, 1983) were injected into oocyte nuclei of Pleurodeles. Neither retraction of the lateral loops nor reduction in the number of transcripts per rRNA gene could be observed with any of the antibodies. Thus, these experiments do not provide evidence for the existence of Z-DNA in transcribed lampbrush loops.

\section{TRANSCRIPT ASSEMBLY AND MATURATION}

The question whether the complex maturation and processing pathways leading to mature mRNAs and rRNAs can be selectively influenced by microinjection of antibodies directed against RNA or specific RNA-associated proteins has so far not been extensively analysed. The only reports that transcript processing can be experimentally modulated in the living cell come from injection of antibodies to small nuclear RNA-protein complexes (snRNPs) into Xenopus oocyte nuclei (Bozzoni et al. 1984; Fradin et al. 1984). As shown by these authors, antibodies directed against U1-containing snRNPs and the Sm-class of snRNPs abolish premRNA splicing in the living cell, similar to that observed using a soluble in vitro system (Padgett, Mount, Steitz \& Sharp, 1983; Krämer, Keller, Appel \& Lührmann, 1984).

The molecular interaction between U1-snRNA and the $5^{\prime}$-splice site of premRNA via specific base pairing is now well understood (e.g. Krämer et al. 1984). A similar role based on specific base pairing has also been proposed for the nucleolus-specific U3-RNA involved in the excision of the 'internal transcribed spacer 2' (ITS 2) between the $5.8 \mathrm{~S}$ and $28 \mathrm{~S}$ rRNA sequences, which converts the $32 \mathrm{~S}$ intermediate precursor into mature $5.8 \mathrm{~S}$ and $28 \mathrm{~S}$ rRNA (Crouch, Kanaya \& Earl, 1983; Bacchellerie, Michot \& Raynai, 1983; Tague \& Gerbi, 1984). U3-RNA contains, like many other nucleoplasmic U-species, a 2,2,7-trimethylguanosine $\left(\mathrm{m}_{3} \mathrm{G}\right)$ cap structure at its 5 '-terminal end (for a review see Reddy \& Busch, 1983). Since antibodies directed against this trimethylated cap are able to inhibit splicing of pre-mRNA in vitro probably by blocking the 5'-terminus of U1-RNA (Krämer et al. 1984) we wondered whether the antibodies would also interfere with the conversion of $32 \mathrm{~S}$ to $28 \mathrm{~S}$ rRNA.

Purified rabbit IgGs specific for the $\mathrm{m}_{3} \mathrm{G}$-cap structure (Lührmann et al. 1982) react, in addition to the nucleoplasmic U-RNA species, with nucleolar U3-RNA as seen by immunofluorescence microscopy using various cultured cell lines. On frozen sections of Xenopus ovaries, the antibodies stain the nucleoplasm and, in particular, the amplified nucleoli (U. Scheer \& R. Lührmann, unpublished data). 
However, after microinjection into Xenopus oocyte nuclei the antibodies do not inhibit accumulation of $28 \mathrm{~S}$ rRNA as determined by gel electrophoresis of labelled RNA extracted from the cytoplasmic fraction.

It is clear that this negative outcome neither rules out nor supports a possible involvement of U3-RNA in the processing of pre-rRNA. Further studies such as injection of U3- snRNP-specific autoantibodies are required to clarify the role played by the nucleolar snRNA species. In addition, antibodies specific to nuclear RNA-binding proteins such as hnRNP core proteins or nucleolar proteins, including specific ribosomal proteins, should be used in future experiments designed to increase our understanding of the complex maturation pathways of RNA transcripts and their association with nuclear structures.

I thank Dr R. Benavente (this institution) for microinjection of DNA-antibodies into cultured cells and Dr W. W. Franke for critical reading of the manuscript. This work received financial support from the Deutsche Forschungsgemeinschaft (grant Sche 157/5-4).

\section{REFERENCES}

Antman, K. H. \& Livingston, D. (1980). Intracellular neutralization of SV 40 tumor antigens following microinjection of specific antibody. Cell 19, 627-635.

BACHellerie, J.-P., Michot, B. \& Raynal, F. (1983). Recognition signals for mouse pre-rRNA processing. Molec. Biol. Rep. 9, 79-86.

BAER, B. W. \& Rhodes, D. (1983). Eukaryotic RNA polymerase II binds to nucleosome cores from transcribed genes. Nature, Lond. 301, 482-488.

Bennett, F. C., Busch, H., Lischwe, M. A. \& Yeoman, L. C. (1983). Antibodies to a nucleolar protein are localized in the nucleolus after red blood cell-mediated microinjection. J. Cell Biol. 97, 1556-1572.

Beroldingen, C. H., Reynolds, W. F., Millstein, L., Bazett-Jones, D. P. \& Gottesfeld, J. M. (1984). Eukaryotic transcription complexes. Mol. Cell Biochem. 62, 97-108.

Blose, S. H., Meltzer, D. I. \& Feramisco, J. R. (1984). 10-nm filaments are induced to collapse in living cells microinjected with monoclonal and polyclonal antibodies against tubulin. J. Cell Biol. 98, 847-858.

Bona, M., Scheer, U. \& Bautz, E. K. F. (1981). Antibodies to RNA polymerase II (B) inhibit transcription in lampbrush chromosomes after microinjection into living amphibian oocytes. J. molec. Biol. 151, 81-99.

Bozzoni, I., Annesi, F., Beccari, E., Pierandrei-Amaldi, P. \& Amaldi, F. (1984). Splicing of Xenopus laevis ribosomal protein RNAs is inhibited in vivo by antisera to ribonucleoproteins containing U1 small nuclear RNA. J. molec. Biol. 180, 1173-1178.

Bréant, B., Huet, J., Sentenac, A. \& Fromageot, P. (1983). Analysis of yeast RNA polymerases with subunit-specific antibodies. J. biol. Chem. 258, 11968-11973.

BURKe, B, \& WARREN, G. (1984). Microinjection of mRNA coding for an anti-Golgi antibody inhibits intracellular transport of a viral membrane protein. Cell 36, 847-856.

Callan, H. G. \& Lloyd, L. (1960). Lampbrush chromosomes of crested newts Triturus cristatus (Laurenti). Proc. R. Soc. B 243, 135-212.

Carroll, S. B. \& Stollar, D. (1982). Inhibitory monoclonal antibody to calf thymus RNA polymerase II blocks formation of enzyme-DNA complexes. Proc. natn. Acad. Sci. U.S.A. 79; $7233-7237$.

Crouch, R. J., Kanaya, S. \& Earl, P. L. (1983). A model for the involvement of the small nucleolar RNA (U3) in processing eukaryotic ribosomal RNA. Molec. Biol. Rep. 9, 75-78.

Dahmus, M. E. \& Kedinger, C. (1983). Transcription of adenovirus-2 major late promoter inhibited by monoclonal antibody directed against RNA polymerase $\mathrm{II}_{\mathrm{O}}$ and $\mathrm{II}_{\mathrm{A}}$. J. biol. Chem. 258, 2303-2307. 
DynAN, W. S. \& TJIAN, R. (1985). Control of eukaryotic messenger RNA synthesis by sequencespecific DNA-binding proteins. Nature, Lond. 316, 774-778.

Egly, J. M., Miyamoto, N. G., Moncollin, V. \& Chambon, P. (1984). Is actin a transcription initiation factor for RNA polymerase B? EMBO J. 3, 2363-2371.

EINCK, L. \& Bustin, M. (1983). Inhibition of transcription in somatic cells by microinjection of antibodies to chromosomal proteins. Proc. natn. Acad. Sci. U.S.A. 80, 6735-6739.

EINCK, L. \& Bustin, M. (1984). Functional histone antibody fragments traverse the nuclear envelope. J. Cell Biol. 98, 205-213.

Fleischmann, G., Pflugfelder, G., Steiner, E. K., Javaherian, K., Howard, G. C., Wang, J. C. \& Elgin, S. C. R. (1984). Drosophila DNA topoisomerase I is associated with transcriptionally active regions of the genome. Proc. natn. Acad. Sci. U.S.A. 81, 6958-6962.

Fradin, A., Jove, R., Hemenway, C., Keiser, H. D., Manley, J. L. \& Prives, C. (1984). Splicing pathways of SV 40 mRNAs in $X$. laevis oocytes differ in their requirements for snRNPs. Cell 37, 927-936.

Gall, J. G. (1966). Techniques of the study of lampbrush chromosomes. In Methods in Cell Physiology, vol. 2 (ed. D. M. Prescott), pp. 37-60. New York: Academic Press.

INGLES, C. J. (1973). Antigenic homology of eukaryotic RNA polymerases. Biochem. biophys. Res. Commun. 55, 364-371.

Johns, E. W. (1982). The HMG Chromosomal Proteins. New York: Academic Press.

Karpov, V. L., Preobrazhenskaya, O. V. \& Mirzabekov, A. D. (1984). Chromatin structure of hsp 70 genes, activated by heat shock: selective removal of histones from the coding region and their absence from the $5^{\prime}$ region. Cell 36, 423-431.

Kleinschmidt, J. A., Scheer, U., Dabauvalle, M.-C., Bustin, M. \& Franke, W. W. (1983). High mobility group proteins of amphibian oocytes: a large storage pool of a soluble high mobility group-1-like protein and involvement in transcriptional events. J. Cell Biol. 97, $838-848$.

Krämer, A., Keller, W., Appel, B. \& Lührmann, R. (1984). The 5' terminus of the RNA moiety of U1 small nuclear ribonucleoprotein particles is required for the splicing of messenger RNA precursors. Cell 38, 299-307.

Lancillotti, F., Lopez, M. C., Alonso, C. \& Stollar, B. D. (1985). Locations of Z-DNA in polytene chromosomes. J. Cell Biol. 100, 1759-1766.

LIN, J. J.-C. \& Feramisco, J. R. (1981). Disruption of the in vivo distribution of the intermediate filaments in fibroblasts through the microinjection of a specific antibody. Cell 24, 185-193.

Lührmann, R., Appel, B., Bringmann, P., Rinke, J., Reuter, R. \& Rothe, S. (1982). Isolation and characterization of rabbit anti- $\mathrm{m}_{3}^{2,2,7} \mathrm{G}$ antibodies. Nucleic Acids Res. 10, 7103-7113.

Mathis, D., Oudet, P. \& Chambon, P. (1980). Structure of transcribing chromatin. Prog. Nucleic Acid Res. molec. Biol. 24, 1-55.

McGarry, T., Hough, R., Rogers, S. \& Rechsteiner, M. (1983). Intracellular distribution and degradation of immunoglobulin $\mathrm{G}$ and immunoglobulin $\mathrm{G}$ fragments injected into HeLa cells. J. Cell Biol. 96, 338-346.

Mercer, W. E., Avignolo, C. \& Baserga, R. (1984a). Role of the p53 protein in cell proliferation as studied by microinjection of monoclonal antibodies. Mol. Cell Biol. 4, 276-281.

Mercer, W. E., Avignolo, C., Galanti, N., Rose, K. M., Hyland, J. K., Jacob, S. T. \& Baserga, R. (1984b). Cellular DNA replication is independent of the synthesis or accumulation of ribosomal RNA. Expl Cell Res. 150, 118-130.

MilleR, O. L. (1981). The nucleolus, chromosomes and visualization of genetic activity. J. Cell Biol. 91, 15s-27s.

Mott, M. R. \& Callan, H. G. (1975). An electron-microscope study of the lampbrush chromosomes of the newt Triturus cristatus. J. Cell Sci. 17, 241-261.

Muller, M. T., Pfund, W. P., Mehta, V. B. \& Trask, D. K. (1985). Eukaryotic type I topoisomerase is enriched in the nucleolus and catalytically active on ribosomal DNA. EMBO J. 4, 1237-1243.

NAKAYASU, H. \& UEDA, K. (1985). Association of rapidly-labelled RNAs with actin in nuclear matrix from mouse L5178Y cells. Expl Cell Res. 160, 319-330.

Nordheim, A., Pardue, M. L., Lafer, E. M., Möller, A., Stollar, B. D. \& Rich, A. (1981). Antibodies to left-handed Z-DNA bind to interband regions of Drosophila polytene chromosomes. Nature, Lond. 294, 417-422. 
Padgett, R. A., Mount, S. M., Steitz, J. A. \& Sharp, P. A. (1983). Splicing of messenger RNA precursors is inhibited by antisera to small nuclear ribonucleoprotein. Cell 35, 101-107.

Pohl, F. M., Thomae, R. \& DiCapua, E. (1982). Antibodies to Z-DNA interact with form V DNA. Nature, Lond. 300, 545-546.

Reddy, R. \& Busch, H. (1983). Small nuclear RNAs and RNA processing. Prog. Nucleic Acid Res. molec. Biol. 30, 127-162.

Reeves, R. (1984). Transcriptionally active chromatin. Biochim. biophys. Acta 782, 343-393.

Reimer, G., Rose, K. M., Scheer, U. \& TAN, E. M. (1986). Autoantibody to RNA polymerase I in scleroderma sera. J. clin. Invest. (submitted).

Rose, K. M., Maguire, K. A., Wurpelt, J. N. D., Stetler, D. A. \& Márquez, E. D. (1983b). Monoclonal antibodies directed against mammalian RNA polymerase I. J. biol. Chem. 258, 12976-12981.

Rose, K. M., Stetler, D. A. \& JAcob, S. T. (1981). Protein kinase activity of RNA polymerase I purified from a rat hepatoma: probable function of $M_{\mathrm{r}} 42,000$ and 24,600 polypeptides. Proc. natn. Acad. Sci. U.S.A. 78, 2833-2837.

Rose, K. M., Stetler, D. A. \& JACob, S. T. (1983a). RNA polymerases from higher eukaryotes. In Enzymes of Nucleic Acid Synthesis and Modification, vol. 2 (ed. S. T. Jacob), pp. 43-74. Boca Raton: CRC Press.

SARGAN, D. R. \& ButTeRworth, P. H. W. (1985). Eukaryotic ternary transcription complexes: transcription complexes of RNA polymerase II are associated with histone-containing, nucleosome-like particles in vivo. Nucleic Acids Res. 13, 3805-3822.

Scheer, U., Hinssen, H., Franke, W. W. \& Jockusch, B. M. (1984). Microinjection of actinbinding proteins and actin antibodies demonstrates involvement of nuclear actin in transcription of lampbrush chromosomes. Cell 39, 111-122.

SCHEer, U. \& Sommerville, J. (1982). Sizes of chromosome loops and hnRNA molecules in oocytes of amphibia of different genome sizes. Expl Cell Res. 139, 410-416.

Scheer, U., Sommerville, J. \& Bustin, M. (1979a). Injected histone antibodies interfere with transcription of lampbrush chromosome loops in oocytes of Pleurodeles. J. Cell Sci. 40, 1-20.

Scheer, U., Spring, H. \& Trendelendurg, M. F. (1979b). Organization of transcriptionally active chromatin in lampbrush chromosome loops. In The Cell Nucleus, vol. 7 (ed. H. Busch), pp. 3-47. New York: Academic Press.

Scheer, U., Trendelenburg, M. F. \& Franke, W. W. (1975). Effects of actinomycin D on the association of newly formed ribonucleoproteins with the cistrons of ribosomal RNA in Triturus oocytes. J. Cell Biol. 65, 163-179.

Scheer, U., Trendelenburg, M. F. \& Franke, W. W. (1976). Regulation of transcription of genes of ribosomal RNA during amphibian oogenesis. J. Cell Biol. 69, 465-489.

SCHEER, U. \& ZENTGRAF, H. (1982). Morphology of nucleolar chromatin in electron microscopic spread preparations. In The Cell Nucleus, vol. 11 (ed. H. Busch \& L. Rothblum), pp. 143-176. New York: Academic Press.

SCHLEgel, R. A., Miller, L. S. \& Rose, K. M. (1985). Reduction in RNA synthesis following red cell-mediated microinjection of antibodies to RNA polymerase I. Cell Biol. Int. Rep. 9, 341-350.

Sekimizu, K., Nakanishi, Y., Mizuno, D. \& Natori, S. (1979). Purification and preparation of antibody to RNA polymerase II stimulatory factors from Ehrlich ascites tumor cells. Biochem. 18, 1582-1588.

Sentenac, A. (1985). Eukaryotic RNA polymerases. CRC Crit. Rev. Biochem. 18, 31-90.

SPRING, H. \& FRANKE, W. W. (1981). Transcriptionally active chromatin in loops of lampbrush chromosomes at physiological salt concentrations as revealed by electron microscopy of sections. Eur. J. Cell Biol. 24, 298-308.

Stacey, D. W. \& Allfrey, V. G. (1984). Microinjection studies of protein transit across the nuclear envelope of human cells. Expl Cell Res. 154, 283-292.

Stetler, D. A., Rose, K. M. \& JACoB, S. T. (1981). Anti-poly(A) polymerase antibodies in sera of tumor-bearing rats and human cancer patients. Proc. natn. Acad. Sci. U.S.A. 78, 7732-7736.

Sugawa, H., Imamoto, N., Wataya-Kaneda, M. \& Uchida, T. (1985). Foreign protein can be carried into the nucleus of mammalian cell by conjugation with nucleoplasmin. Expl Cell Res. 159, 419-429. 
TAgue, B. W. \& Gerbi, S. A. (1984). Processing of the large rRNA precursor: two proposed categories of RNA-RNA interactions in eukaryotes. J. molec. Evol. 20, 362-367.

Thomae, R., Beck, S. \& Pohl, F. M. (1983). Isolation of Z-DNA containing plasmids. Proc. natn. Acad. Sci. U.S.A. 80, 5550-5553.

Ueno, K., Sekimizu, K., Mizuno, D. \& Natori, S. (1979). Antibody against a stimulatory factor of RNA polymerase II inhibits nuclear RNA synthesis. Nature, Lond. 277, 145-146.

WANG, J. C. (1985). DNA topoisomerases. A. Rev. Biochem. 54, 665-697.

Weisbrod, S. (1982). Active chromatin. Nature, Lond. 297, 289-295.

Yamaizumi, M., Uchida, T., Mekeda, E. \& OKada, Y. (1979). Antibodies introduced into living cells by red cell ghosts are functionally stable in the cytoplasm of the cells. Cell 18, 1009-1014. 